\title{
Relapse of clinical symptoms of COVID-19 or probable reinfection in a laboratory professional: a case report from Northeast Brazil
}

Recidiva de sintomas clínicos da COVID-19 ou provável reinfecção em profissional de laboratório: relato de caso no Nordeste do Brasil

Recurrencia de síntomas clínicos de COVID-19 o probable reinfección en un profesional de laboratorio: reporte de un caso en el noreste de Brasil

\begin{abstract}
Healthcare professionals constitute one of the groups that are most vulnerable to severe acute respiratory syndrome coronavirus 2 (SARS-CoV-2). Herein, we report the case of a non-overweight and non-smoking 42-year-old woman with thrombophilia due to methylenetetrahydrofolate reductase (MTHFR) gene mutation, hereditary renal cysts, and no history of diabetes or arterial hypertension, who presented the first symptoms between 10 and 17 August 2020, with a SARS-CoV-2-positive naso-oropharyngeal swab by qualitative real-time polymerase chain reaction (RT-PCR). However, the result for SARS-CoV-2 immunoglobulin G (IgG) was non-reactive 41 days after (21 September 2020) the onset of symptoms. Nevertheless, on 7 October 2020 (57 days after the first symptoms), the patient presented new symptoms suggestive of COVID-19, with another SARS-CoV-2-positive RT-PCR result, and on 21 October 2020, SARS-CoV-2 immunoglobulin $\mathrm{G}$ was positive. Considering this, we interrogated the results to determine whether the case was reinfection or reactivation. This outcome highlights the importance of surveillance over relapses or
\end{abstract} reinfections.

Keywords: COVID-19; Severe acute respiratory syndrome coronavirus 2; Recurrence.

\section{Resumo}

Os profissionais de saúde constituem um dos grupos mais vulneráveis à síndrome respiratória aguda grave pelo coronavírus 2 (SARS-CoV-2). Neste artigo, relatamos o caso de uma mulher de 42 anos de idade, sem excesso de peso e não fumante, com trombofilia devido à mutação do gene metinelotetrahidrofolato redutase (MTHFR), cistos renais hereditários e sem história de diabetes ou hipertensão arterial, que apresentou os primeiros sintomas entre 10 e 
17 de agosto de 2020, com um swab naso-orofaríngeo positivo para SARS-CoV-2 por reação em cadeia da polimerase qualitativa em tempo real (RT-PCR). No entanto, o resultado da imunoglobulina G (IgG) SARS-CoV-2 foi não reativo 41 dias após o início dos sintomas (21 de setembro de 2020). Em 7 de outubro de 2020 (57 ias após os primeiros sintomas), a paciente apresentou novos sintomas sugestivos da COVID-19, com outro resultado de RT-PCR SARS-CoV-2 positivo, e em 21 de outubro de 2020, SARS-CoV-2 IgG foi reagente. Diante disso, interrogamos os resultados para determinar se o caso foi uma reinfecção ou reativação. Este caso destaca a importância da vigilância epidemiológica sobre recaídas ou reinfecções do SARS-CoV-2.

Palavras-chave: COVID-19; Síndrome respiratória aguda grave; Reinfecção.

\section{Resumen}

Los profesionales de la salud son uno de los grupos más vulnerables al síndrome respiratorio agudo severo por coronavirus 2 (SARS-CoV-2). En este artículo presentamos el caso de una mujer de 42 años, sin sobrepeso y no fumadora, con trombofilia por mutación del gen de la metinotetrahidrofolato reductasa (MTHFR), quistes renales hereditarios y sin antecedentes de diabetes o arterias. hipertensos, quienes presentaron los primeros síntomas entre el 10 y el 17 de agosto de 2020, con hisopo naso-orofaríngeo positivo para SARS-CoV-2 por reacción en cadena de la polimerasa cualitativa en tiempo real (RT-PCR). Sin embargo, el resultado de la inmunoglobulina G (IgG) del SARSCoV-2 no fue reactivo 41 días después del inicio de los síntomas (21 de septiembre de 2020). El 7 de octubre de 2020 (57 días después de los primeros síntomas), la paciente presentó nuevos síntomas sugestivos de COVID-19, con otro resultado de RT-PCR positiva para SARS-CoV-2, y el 21 de octubre de 2020, SARS-CoV- 2 IgG fue el reactivo. Por tanto, cuestionamos los resultados para determinar si se trataba de una reinfección o una reactivación. Este caso destaca la importancia de la vigilancia epidemiológica de las recaídas o reinfecciones del SARS-CoV-2.

Palabras clave: COVID-19; Síndrome respiratorio agudo severo; Reinfección.

\section{Introduction}

Atypical pneumonia was first identified in Wuhan, Hubei Province, China, in December 2019, with a rapid increase in hospitalisations. The etiologic agent of the disease wasm designated as the 2019 novel coronavirus (2019-nCoV) and later, as severe acute respiratory syndrome coronavirus 2 (SARS-CoV-2). In early 2020, China rapidly became the epicentre of this epidemic, designated by the World Health Organization (Wiersinga et al., 2020) as the coronavirus disease 2019 (COVID-19). However, the virus has spread rapidly on all continents, causing high rates of morbidity, hospitalizations and mortality, especially in populations characterized as the highest risk, such as: obsedity, hypertension, diabetes, chronic lung diseases, pregnancy and immunosuppression (Kambhampati et al., 2020).

Recently, SARS-CoV-2, because it is a more complex genome when compared to other RNA viruses, has shown different mutations in the Spike (S) region of its genome, which have aroused the interest of researchers, as they may be related increases in transmissibility, pathogenicity or immune escape from vaccines (Altmann, Rosemary \& Beale, 2021). These variants, with a great possibility of pandemic impact, are called variants of concern (VOCs) and are classified according to the presence of different non-synonymous mutations present in the S region of the SARS-CoV-2 genome. Studies have shown that some VOCs have greater resistance to neutralizing antibodies directed at some subregions of protein S (WANG et al., 2021). On the other hand, it has also been speculated about the greater likelihood of reinfections, which would affect health professionals, given their high exposure to the virus. Despite the greater resistance to some neutralizing antibodies, until now, it has been evaluated that vaccines cope well in controlling VOCs (Gómes, Perdiguero \& Esteban, 2021).

Healthcare professionals constitute one of the groups that are most vulnerable to SARS-CoV-2 infection. In Brazil, the infection rate among these professionals, with respect to the total number of cases, varies from $6.9 \%$ to $30.4 \%$, reflecting a high prevalence (Pessa Valente et al., 2020). Cases of reinfections and recurrences of SARS-CoV-2 infection have drawn much attention because of the growing number of reports (Chen et al., 2020; Yuan et al., 2020). Thus, we report the possibility of either recurrence or reinfection by SARS-CoV-2 in a health professional working in a clinical laboratory in Northeast Brazil. 


\section{Methodology}

The study represents a Case Study (case report) in which we analyzed the clinical and laboratory aspects of a patient seen at the Hospital das Clínicas of the Federal University of Pernambuco, in which the clinical and laboratory characteristics of the first infection and possible relapse and / or relapse were evaluated. reinfection. For the laboratory diagnosis, the SARSCoV-2 IgG detection test by the chemiluminescence methodology (Abbott, USA) and the RT-PCR assay was performed by the CDC 2019-Novel Coronavirus kit (2019-nCoV) were used. The patient voluntarily signed an informed consent form. The authors declare that the study is following the Code of Ethics of the World Medical Association (Declaration of Helsinki).

\section{Results}

A non-smoking and non-overweight 42-year-old woman, laboratory analyst, with thrombophilia due to methylenetetrahydrofolate reductase (MTHFR) gene mutation, hereditary renal cysts, no history of diabetes or high blood pressure, and regular vaccination for influenza in 2020, presented with headache, nasal congestion, and asthenia between 10 and 17 August 2020. On 13 August 2020, the naso-oropharyngeal swab test by qualitative real-time reverse transcription polymerase chain reaction (RT-PCR) assay was positive for SARS-CoV-2. The patient denied direct contact with other patients, health professionals, or home contacts with SARS-CoV-2-positive laboratory results and/or suggestive symptoms. Concurrently, the patient claimed to have undergone only symptomatic treatment with $500 \mathrm{mg}$ paracetamol to relieve flu-like symptoms (Figure 1).

Figure 1. Timeline of molecular diagnosis, serological assays and symptoms from the case report.

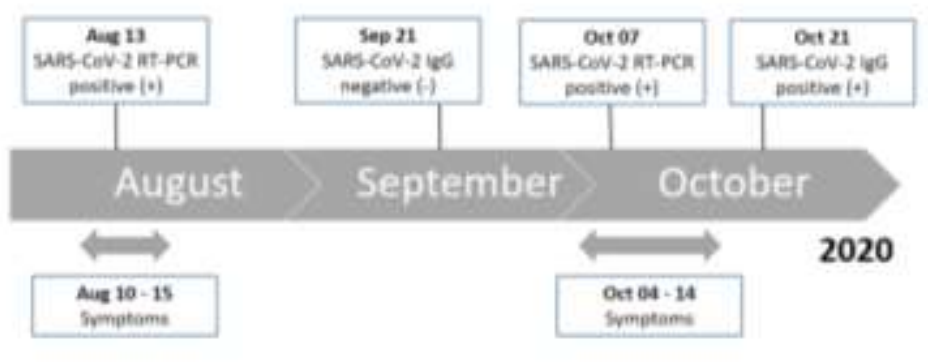

Source: Authors.

Forty-one days after the onset of the first symptoms, the patient underwent a SARS-CoV-2 IgG detection by the chemiluminescence methodology (Abbott, USA), which result was non-reactive. Between 4 and 14 October 2020, the patient reported many symptoms: myalgia, sore throat, asthenia, headache, nasal congestion, cough, poor appetite, fever, and diarrhoea. On 7 October 2020, a new RT-PCR assay was performed, with a positive result. The time interval between the two positive RT-PCRs was 55 days. On both occasions when RT-PCR for SARS-CoV-2 was performed, no computed tomography (CT) scans and assays for other respiratory viruses or bacterial cultures of the upper or lower respiratory tracts were performed. Due to the intense symptoms on the second episode, it was administered paracetamol (500 mg), azithromycin (500 $\mathrm{mg})$, and prednisone $(40 \mathrm{mg})$, with the latter two administered for 5 days.

On the reappearance of COVID-19 symptoms, the patient reported that a few days before, she came into contact with other health professionals at her workplace who had characteristic symptoms and SARS-CoV-2-positive RT-PCR results. The symptoms were completely resolved, without post-COVID-19 sequels, until the time of writing this case report. Finally, on 21 October 2020, the patient underwent a new SARS-CoV-2-antibody detection by chemiluminescence, the result of which was 
reactive. Thus, we found that the patient developed IgG antibodies against SARS-CoV-2 after the second episode of symptoms.

\section{Discussion}

We report a case of a health professional with recurrence of COVID-19 symptoms within 57 days. In both episodes of COVID-19, RT-PCR for SARS-CoV-2 was positive; however, IgG for SARS-CoV-2 was detected only after the second one. Since the description of the first case of reinfection by SARS-CoV-2 in Hong Kong (China) (TO et al., 2020), several other reports of reinfection or recurrence have been published (Tillett et al., 2020; Fernandes Valente Takeda et al., 2020). Healthcare workers have a greater risk of SARS-CoV-2 infection and, in Brazil, the frequency of COVID-19-positive cases in healthcare has varied between 6.9 and 30.4\% of the total cases (Pessa Valente et al., 2020). In addition, the country has the third highest number of cases in the world, and some SARS-CoV-2 reinfections and/or recurrences have been described in health professionals (Fernandes Valente Takeda et al., 2020; Bonifácio et al., 2020).

On both symptomatic episodes, the patient presented with mild illness, i.e., absence of shortness of breath or dyspnea; however, IgG for the virus was detected only after the second symptomatic episode. It has been suggested that the magnitude of the antibody response appears to be associated with disease severity (Seow et al., 2020); therefore, in the first stage of symptomatology, the patient may not have produced antibodies at levels suitable for serological detection. We emphasise that, despite this possibility, we found the existence of a false positive for any of the RT-PCRs unlikely since in both episodes the patient presented flu-like symptoms and belonged to a group at greater risk of SARS-CoV-2 infection. As a non-reactive result for SARS-CoV-2 IgG is presented in the first stage of symptoms, we suspect that it was a false-negative result. However, the manufacturer indicates that the sensitivity of the test is $100 \%$ in cases where the collection of the sample occurs after 14 days of symptoms. In this case study, this period was 41 days.

The case study has some limitations, for example, the absence of other biochemical and haematological laboratory tests prevented the observation of a likely correlation between clinical, virological, and laboratory data. The fact that RT-PCR for SARS-CoV-2 was not performed in the interstice between the two positive results for the molecular test prevented the elucidation of a possible definition of reinfection. This case report alludes to the possible occurrence of viral reactivation or reinfection, which we cannot classify with the data obtained. Additionally, a chronic case of COVID-19 has been described in a patient with lymphoma and associated B-cell immunodeficiency, who may act as a persistent source of transmission (BAANG et al., 2020); however, the present case report does not relate to any immunodeficiency. Thus, because of the numerous studies that have reported possible reinfections and/or recurrences of SARS-CoV-2, the importance of the continued use of personal protective equipment by healthcare is emphasised.

\section{Conclusion}

The presentation of two distinct symptomatic periods at an interval of 57 days, with a second positive SARS-CoV-2 RT-PCR exam, makes us question the results to determine whether the case was a reinfection or reactivation. Therefore, the importance of epidemiological surveillance on SARS-CoV-2 relapses or reinfections is highlighted. Mainly, after the identification and emergence of numerous VOCs in different regions of the planet, which may be related to higher rates of transmission, pathogenesis and resistance to some neutralizing antibodies. Thus, continuous clinical, laboratory and genomic surveillance are important for better containment of the pandemic and attention to clinical symptoms related to relapses and / or reinfections. 


\section{References}

Altmann, D. M., Boyton, R. J., \& Beale, R. (2021). Immunity to SARS-Cov-2 variants of concern. Science, 371(6534), 1103-1104. https://doi.org/10.1126/science.abg7404

Baang, J. H., Smith, C., Mirabelli, C., Valesano, A. L., Manthei, D. M., Bachman, M. A., Wobus, C. E., Adams, M., Washer, L., Martin, E. T., \& Lauring, A. S. (2020). Prolonged severe acute respiratory syndrome coronavirus 2 replication in an Immunocompromised patient. The Journal of Infectious Diseases, 223(1), 23-27. https://doi.org/10.1093/infdis/jiaa666

Bonifácio, L. P., Pereira, A. P., Araújo, D. C., Balbão, V. D., Fonseca, B. A., Passos, A. D., \& Bellissimo-Rodrigues, F. (2020). Are SARS-Cov-2 reinfection and COVID-19 recurrence possible? a case report from Brazil. Revista da Sociedade Brasileira de Medicina Tropical, 53. https://doi.org/10.1590/0037-86820619-2020

Chen, D., Xu, W., Lei, Z., Huang, Z., Liu, J., Gao, Z., \& Peng, L. (2020). Recurrence of positive SARS-Cov-2 RNA in COVID-19: A case report. International Journal of Infectious Diseases, 93, 297-299. https://doi.org/10.1016/j.ijid.2020.03.003

Fernandes Valente Takeda, C., Moura de Almeida, M., Gonçalves de Aguiar Gomes, R., Cisne Souza, T., Alves de Lima Mota, M., Pamplona de Góes Cavalcanti, L., \& Baima Colares, J. K. (2020). Case report: Recurrent clinical symptoms of COVID-19 in healthcare professionals: A series of cases from Brazil. The American Journal of Tropical Medicine and Hygiene, 103(5), 1993-1996. https://doi.org/10.4269/ajtmh.20-0893

Gómez, C. E., Perdiguero, B., \& Esteban, M. (2021). Emerging SARS-Cov-2 variants and impact in global vaccination programs against SARS-Cov2/COVID-19. Vaccines, 9(3), 243. https://doi.org/10.3390/vaccines9030243

Kambhampati, A. K., O’Halloran, A. C., Whitaker, M., Magill, S. S., Chea, N., Chai, S. J., Daily Kirley, P., Herlihy, R. K., Kawasaki, B., Meek, J., YouseyHindes, K., Anderson, E. J., Openo, K. P., Monroe, M. L., Ryan, P. A., Kim, S., Reeg, L., Como-Sabetti, K., \& Danila, R. (2020). COVID-19-associated hospitalizations among health care personnel - COVID-NET, 13 states, March 1-May 31, 2020. MMWR. Morbidity and Mortality Weekly Report, 69(43), 1576-1583. https://doi.org/10.15585/mmwr.mm6943e3

Pessa Valente, E., Cruz Vaz da Costa Damásio, L., Luz, L. S., Da Silva Pereira, M. F., \& Lazzerini, M. (2020). COVID-19 among health workers in Brazil: The silent wave. Journal of Global Health, 10(1). https://doi.org/10.7189/jogh.10.010379

Seow, J., Graham, C., Merrick, B., Acors, S., Pickering, S., Steel, K. J., Hemmings, O., O’Byrne, A., Kouphou, N., Galao, R. P., Betancor, G., Wilson, H. D., Signell, A. W., Winstone, H., Kerridge, C., Huettner, I., Jimenez-Guardeño, J. M., Lista, M. J., Temperton, N., \& Doores, K. J. (2020). Longitudinal observation and decline of neutralizing antibody responses in the three months following SARS-Cov-2 infection in humans. Nature Microbiology, 5(12), 1598-1607. https://doi.org/10.1038/s41564-020-00813-8

Tillett T.L, Sevinsky J.R, Hartley P.D, et al. (2020). Genomic evidence for reinfection with SARS-CoV-2: a case study. The Lancet Infectious Diseases, 20(9), e215. https://doi.org/10.1016/s1473-3099(20)30608-3

To, K. K., Hung, I. F., Ip, J. D., Chu, A. W., Chan, W., Tam, A. R., Fong, C. H., Yuan, S., Tsoi, H., Ng, A. C., Lee, L. L., Wan, P., Tso, E. Y., To, W., Tsang, D. N., Chan, K., Huang, J., Kok, K., Cheng, V. C., \& Yuen, K. (2020). Coronavirus disease 2019 (COVID-19) re-infection by a phylogenetically distinct severe acute respiratory syndrome coronavirus 2 strain confirmed by whole genome sequencing. Clinical Infectious Diseases. https://doi.org/10.1093/cid/ciaa1275

Wang, P., Nair, M. S., Liu, L., Iketani, S., Luo, Y., Guo, Y., Wang, M., Yu, J., Zhang, B., Kwong, P. D., Graham, B. S., Mascola, J. R., Chang, J. Y., Yin, M. T., Sobieszczyk, M., Kyratsous, C. A., Shapiro, L., Sheng, Z., Huang, Y., \& Ho, D. D. (2021). Antibody resistance of SARS-Cov-2 variants B.1.351 and B.1.1.7. https://doi.org/10.1101/2021.01.25.428137

Wiersinga, W. J., Rhodes, A., Cheng, A. C., Peacock, S. J., \& Prescott, H. C. (2020). Pathophysiology, transmission, diagnosis, and treatment of coronavirus disease 2019 (COVID-19). JAMA, 324(8), 782. https://doi.org/10.1001/jama.2020.12839

Yuan, B., Liu, H., Yang, Z., Chen, Y., Liu, Z., Zhang, K., Wang, C., Li, W., An, Y., Wang, J., \& Song, S. (2020). Recurrence of positive SARS-Cov-2 viral RNA in recovered COVID-19 patients during medical isolation observation. Scientific Reports, 10(1). https://doi.org/10.1038/s41598-020-68782-w 